\title{
AMPICILLIN IN PAEDIATRICS
}

\author{
BY \\ R. B. ELLIOTT, E. JOAN STOKES and G. M. MAXWELL \\ From the Department of Child Health, the University of Adelaide, Adelaide Children's Hospital, \\ North Adelaide, South Australia
}

(RECEIVED FCR PUBLICATION JULY 17, 1963)

Ampicillin ('penbritin')*, 6-[D(-)- $\alpha$-aminophenylacetamido] penicillanic acid, is a member of the semi-synthetic group of penicillins; it is active when given by mouth, and its antibiotic spectrum includes certain Gram-negative organisms.

The purpose of the present study was to assess the blood levels attainable in the paediatric agegroup, the in vitro sensitivity pattern of selected organisms, and the response to ampicillin therapy in certain childhood diseases.

\section{Methods and Patients}

Blood Concentrations After Oral Dosage. Ampicillin was administered as a freshly prepared oral suspension in a dose of $12.5 \mathrm{mg}$. $/ \mathrm{kg}$. to 38 children who were in hospital with a variety of acute and chronic diseases. They were not fasted and had not received antibiotics. Blood was collected before the dose and at hourly intervals afterwards. Four other children received $25 \mathrm{mg} . / \mathrm{kg}$., and seven children $50 \mathrm{mg}$. $/ \mathrm{kg}$. The age range of all these children is shown in Table 1. The cup plate assay method for ampicillin concentrations was similar to that described by Knudsen, Rolinson and Stevens (1961).

Liquor Amnii and Cerebrospinal Fluid Concentrations. Two hours after being given $750 \mathrm{mg}$. of ampicillin, amniotic fluid was collected from four women who had obstetric indications for artificial rupture of the membranes. The fluid was assayed for ampicillin activity.

Seven children who were undergoing diagnostic or therapeutic spinal taps were given ampicillin 12.5 $\mathrm{mg} . / \mathrm{kg}$. orally at various times before tapping. The cerebrospinal fluid ampicillin concentrations were assayed in a manner similar to blood. In addition, one child who was undergoing therapeutic cerebrospinal fluid drainage following craniotomy for cerebral tumour had repeated dosage and sampling over five days. One newborn baby with Esch. coli meningitis complicating a meningomyelocele had ventricular fluid assays performed repeatedly during a course of ampicillin of $50 \mathrm{mg} . / \mathrm{kg} . / \mathrm{day}$.

- Supplied by the courtesy of Beecham Research Laboratories.
Minimal In Vitro Inhibitory Concentrations. Gastrointestinal pathogens were collected from 66 children over a ten months' period. Cultures of organisms, identified by standard bacteriological techniques, were subjected to various concentrations of ampicillin under quantitative conditions previously described (Kneebone and Maxwell, 1960).

In Vivo Activity of Ampicillin in Childhood Gastroenteritis. 88 children were admitted to the trial over a period of nine months. The diagnosis of gastroenteritis was confirmed during the first 24 hours of their admission. Ampicillin (50 mg./kg./day) or a placebo were administered as coded mixtures according to strict rotation. The colour of the vehicle and the code were changed from time to time to assure adherence to the 'double-blind' technique of study. The methods of assessing clinical and bacteriological 'cure' were as previously described (Elliott, Maxwell and Kneebone, 1963).

Clinical Trial in Childhood Pneumonia and Urinary Tract Infections. No attempt to assess the efficiency of the antibiotic by controlled trial was made. The clinical course of these two diseases was assessed, and recorded during treatment, to see whether the results accorded with previous clinical experience with other antibiotics.

\section{Results}

Blood Concentrations Attained After Single Oral Dose. Peak concentrations of mean $2.97 \mu \mathrm{g} . / \mathrm{ml}$.

TABLE 1

AGE DISTRIBUTION OF CHILDREN STUDIED

\begin{tabular}{c|c}
\hline Age (yrs.) & Number \\
\hline$<6 / 12$ & 4 \\
$6 / 12-12 / 12$ & 7 \\
$13 / 12-24 / 12$ & 4 \\
$2-4$ & 8 \\
$4-6$ & 4 \\
$6-8$ & 4 \\
$8-10$ & 5 \\
$11-13$ & 2 \\
\hline Total & 38 \\
\hline
\end{tabular}


TABLE 2

BLOOD CONCENTRATIONS AT VARIOUS TIMES AFTER ORAL DOSE OF $12.5 \mathrm{mg} . / \mathrm{kg}$. AMPICILLIN

\begin{tabular}{|c|c|c|c|c|}
\hline & \multicolumn{4}{|c|}{ Time After Dose } \\
\hline & $1 \mathrm{hr}$. & 2 hrs. & 4 hrs. & $6 \mathrm{hrs}$. \\
\hline $\begin{array}{l}\text { Mean level with } \\
\text { S.D. ( } \mu \mathrm{g} . / \mathrm{ml} .)\end{array}$ & $2 \cdot 06 \pm 1 \cdot 32$ & $2 \cdot 97 \pm 2 \cdot 36$ & $1 \cdot 30 \pm 1 \cdot 31$ & $0.95 \pm 1.62$ \\
\hline Range ( $\mu \mathrm{g} . / \mathrm{ml})$. & $0 \cdot 36-7 \cdot 2$ & $0 \cdot 15-11 \cdot 2$ & $0 \cdot 1-5 \cdot 5$ & $-8 \cdot 32$ \\
\hline
\end{tabular}

TABLE 3

BLOOD LEVELS $(\mu \mathrm{g} . / \mathrm{ml}$ ) AFTER $12.5 \mathrm{mg} . / \mathrm{kg}$. AMPICILLIN RELATED TO AGE-GROUPS

\begin{tabular}{|c|c|c|c|c|}
\hline \multirow{2}{*}{$\underset{\text { (yrs.) }}{\text { Age-group }}$} & \multicolumn{4}{|c|}{ Time After Dose } \\
\hline & $1 \mathrm{hr}$. & $2 \mathrm{hrs}$ & 4 hrs. & $6 \mathrm{hrs}$. \\
\hline $0-1$ & $\begin{array}{r}3.26 \\
\pm 1.99\end{array}$ & $\begin{array}{r}3 \cdot 77 \\
\pm 1 \cdot 36\end{array}$ & $\begin{array}{r}1.70 \\
\pm 0.68\end{array}$ & $\begin{array}{r}2 \cdot 16 \\
\pm 2.60\end{array}$ \\
\hline $1-3$ & $\begin{array}{r}1.69 \\
\pm 0.79\end{array}$ & $\begin{array}{r}1.45 \\
\pm 0.69\end{array}$ & $\begin{array}{r}0.57 \\
\pm 0.54\end{array}$ & $\begin{array}{r}0.22 \\
\pm 0.53\end{array}$ \\
\hline $6-12$ & $\begin{array}{r}1.93 \\
\pm 0.83\end{array}$ & $\begin{array}{r}3 \cdot 79 \\
\pm 2 \cdot 37\end{array}$ & $\begin{array}{r}1.46 \\
\pm 1.48\end{array}$ & $\begin{array}{r}0.62 \\
\pm 0.65\end{array}$ \\
\hline
\end{tabular}

Figures are group means with S.D.

were attained at two hours (Table 2). This concentration did not depend on age (Table 3). At six hours the concentration had dropped to negligible levels. Children with gastro-enteritis tended to have lower peak blood levels than children with other disorders (Table 4). This result was statistically significant $(\mathrm{p}<0.01)$. Doubling and quadrupling the dosage appeared to have a like effect on the peak blood levels (Table 5), similar to other penicillins.

Liquor Amnii Concentrations. In one specimen the level obtained was $0.12 \mu \mathrm{g} . / \mathrm{ml}$. with no apparent inhibition of activity in undiluted fluid. However, in the remaining three specimens, no activity could be found until dilution was carried out. Then minimal $(<0 \cdot 1 \mu \mathrm{g} . / \mathrm{ml}$.) concentrations could be found.

Cerebrospinal Fluid Levels. In five children, with no meningeal disorder, no ampicillin activity could be detected at any time between one and six hours after oral dosage. In one child with mild mumps meningoencephalitis, a minimal concentration $(0 \cdot 01$ $\mu \mathrm{g} . / \mathrm{ml}$.) was found.

The child who had undergone brain surgery showed an initial level of $0.68 \mu \mathrm{g} . / \mathrm{ml}$. cerebrospinal fluid. This level after ampicillin dosage declined pari passu with the decline in blood concentration of the fluid.

Ventricular fluid from the case of Esch. coli
TABLE 4

EFFECT OF GASTRO-ENTERITIS ON BLOOD LEVELS $(\mu \mathrm{g} . / \mathrm{ml}$.) OF AMPICILLIN AFTER DOSE OF $12.5 \mathrm{mg} . / \mathrm{kg}$.

\begin{tabular}{|c|c|c|c|c|}
\hline & \multicolumn{4}{|c|}{ Time After Dose } \\
\hline & $1 \mathrm{hr}$. & $2 \mathrm{hrs}$. & 4 hrs. & $6 \mathrm{hrs}$ \\
\hline $\begin{array}{c}\text { Cases with gastro- } \\
\text { enteritis }\end{array}$ & $\begin{array}{r}2.07 \\
\pm 1.69\end{array}$ & $\begin{array}{l}1.96^{*} \\
\pm 1 \cdot 34\end{array}$ & $\begin{array}{r}1.03 \\
\pm 1.37\end{array}$ & $\begin{array}{r}1 \cdot 16 \\
\pm 2 \cdot 21\end{array}$ \\
\hline Others & $\begin{array}{r}2 \cdot 39 \\
\pm 1 \cdot 44\end{array}$ & $\begin{array}{r}4 \cdot 0 \\
\pm 2 \cdot 7\end{array}$ & $\begin{array}{r}1.47 \\
\pm 1.20\end{array}$ & $\begin{array}{r}0.78 \\
\pm 1.00\end{array}$ \\
\hline
\end{tabular}

* Statistically significant at $5 \%$ level.

Figures are group means with S.D.

TABLE 5

EFFECT OF DOUBLING AND QUADRUPLING DOSE OF AMPICILLIN ON BLOOD LEVELS

\begin{tabular}{|c|c|c|c|c|}
\hline & \multicolumn{4}{|c|}{ Time After Dose } \\
\hline & $1 \mathrm{hr}$. & $2 \mathrm{hrs}$. & 4 hrs. & $6 \mathrm{hrs}$. \\
\hline Blood level ( $\mu \mathrm{g} . / \mathrm{ml})$. & \multicolumn{4}{|c|}{\begin{tabular}{r|r}
\multicolumn{2}{|c}{ Dose, $25 \mathrm{mg} / \mathrm{kg}}$. \\
3.58 & $2 \cdot 15$ \\
$\pm 2 \cdot 12$ & $\pm 1 \cdot 33$
\end{tabular}} \\
\hline Blood level $(\mu \mathrm{g} . / \mathrm{ml}$.) & \multicolumn{4}{|c|}{\begin{tabular}{r|r}
\multicolumn{2}{|c|}{ Dose, $50 \mathrm{mg} . / \mathrm{kg}}$. \\
7.99 \\
\pm 2.74 & $\mathbf{4} .71$ \\
21.77
\end{tabular}} \\
\hline
\end{tabular}

Figures are group means with S.D.

meningitis showed levels ranging from 0.09 to $0.6 \mu \mathrm{g} . / \mathrm{ml}$. This latter level was attained during regular six-hourly dosage $(50 \mathrm{mg} . / \mathrm{kg}$./day).

Minimal Inhibitory Concentrations. The gastrointestinal pathogens tested were surprisingly resistant to the effects of ampicillin: only $73 \%$ were sensitive to concentrations of $3.12 \mu \mathrm{g} . / \mathrm{ml}$. (Table 6). Of particular interest was the relative resistance of various serotypes of pathogenic Esch. coli. The salmonella group were the least resistant.

In Vivo Efficacy in Gastro-enteritis. The results of this trial have been assessed by two criteria: the relief of symptoms, and clearing from the bowel of pathogens. Accordingly the patients have been analysed in two main groups: those from whom no bowel pathogen was isolated, and those with an established bacterial infection. A further subdivision into grades of severity on admission was made for purposes of comparison. The treated and control groups were reasonably congruous for age, severity of disease and type of organism isolated. The distribution of the cases is shown in Table 7.

The results were submitted to statistical analysis by the fourfold table method, with Yates correction for small numbers. Statistical significance was accepted at the $5 \%$ level.

Compared with the similar untreated controls, 
TABLE 6

ASSESSMENT OF SENSITIVITY IN VITRO

\begin{tabular}{|c|c|c|c|c|c|c|c|c|c|}
\hline \multirow{2}{*}{\multicolumn{2}{|c|}{ Organism }} & \multirow{2}{*}{$\begin{array}{l}\text { No. } \\
\text { Tested }\end{array}$} & \multicolumn{7}{|c|}{ Minimum Inhibitory Concentrations ( $\mu \mathrm{g} . / \mathrm{ml})}$. \\
\hline & & & $25 \mu \mathrm{g}$. & $12 \cdot 5 \mu \mathrm{g}$ & $6.25 \mu \mathrm{g}$. & $3 \cdot 12 \mu \mathrm{g}$. & $1.56 \mu \mathrm{g}$ & $0.78 \mu \mathrm{g}$. & $0.39 \mu \mathrm{g}$. \\
\hline $\begin{array}{l}\text { Salmonella typhi } \\
\text { S. newport } \\
\text { S. bovis morbific } \\
\text { S. potsdam } \\
\text { S. saint paul } \\
\text { S. oranienburg } \\
\text { S. adelaide } \\
\text { S. enteritidis } \\
\text { Sh. sonnei } \\
\text { Sh. flexneri } \\
\text { Esch. coli (7) } \\
\text { O } 26 \text { B6 } \\
\text { O } 11 \text { B4 } \\
\text { O } 55 \text { B5 } \\
\text { O } 111 \text { B4 } \\
\text { O } 6 \\
\text { O } 26 \\
\text { O } 127\end{array}$ & $\begin{array}{cc}\text { imurium } & . \\
\ldots & \cdots \\
\text { ans } & \cdots \\
\ldots & \cdots \\
\ldots & \cdots \\
\ldots & \cdots \\
\ldots & \cdots \\
\ldots & \cdots \\
\ldots & \ldots \\
\ldots & \cdots\end{array}$ & $\begin{array}{r}33 \\
3 \\
2 \\
2 \\
1 \\
1 \\
1 \\
13 \\
1\end{array}$ & $\begin{array}{l}11 \text { greater than } 25 \\
\mu \mathrm{g} . / \mathrm{ml} ., 3 \text { insensitive } \\
\text { Insensitive } \\
\text { Insensitive }\end{array}$ & 1 & $\begin{array}{l}1 \\
1 \\
1 \\
1\end{array}$ & $\begin{array}{r}17 \\
1 \\
1 \\
1 \\
2 \\
1\end{array}$ & $\begin{array}{r}14 \\
1 \\
1 \\
1 \\
1 \\
1\end{array}$ & $\begin{array}{l}2 \\
1\end{array}$ & \\
\hline
\end{tabular}

TABLE 7

GASTRO-ENTERITIS TRIAL: DISTRIBUTION OF PATIENTS BY GRADE OF SEVERITY AND TYPE OF DISEASE

\begin{tabular}{c|c|c|c|c}
\hline & $\begin{array}{c}\text { Grade 1 } \\
\text { (mild) }\end{array}$ & $\begin{array}{c}\text { Grade 2 } \\
\text { (moderate) }\end{array}$ & $\begin{array}{c}\text { Grade 3 } \\
\text { (severe) }\end{array}$ & Total \\
\hline No pathogen isolated & 23 & 16 & 19 & 58 \\
Pathogen isolated & 14 & 8 & 8 & 30 \\
\hline Total & 37 & 24 & 27 & 88 \\
\hline
\end{tabular}

children with no bowel pathogen did not fare better symptomatically when treated with ampicillin at any time after admission. This applied to all grades of severity of the disease. Similar results pertained to the mildest grade of gastro-enteritis associated with an isolated bowel pathogen. However, in the combined data for moderate and severe disease of this type, at the fourth and sixth day of treatment, the ampicillin group tended to do better symptomatically. The trend failed to gain statistical significance $(0.2>p>0 \cdot 1)$ (Table 8$)$. A similar trend to earlier clearing of stool pathogens was observed in the more severe grades (Table 9).

On analysing the results by grouping according to variety of organisms, a trend to earlier symptomatic and bacteriological cure in the salmonella group emerged (Table 10).

Urinary Tract Infections. Brisk and sustained clearing of infection was attained in two cases in which there was no anatomical basis for the infection, and the organism was found to be sensitive to ampicillin by standard disc techniques. The remaining two cases had either an insensitive organism or underlying congenital lesion and did not respond completely.

Pneumonia. Only the results of treatment of undoubted cases of pneumonia have been recorded. This diagnosis was arrived at in retrospect by three clinicians independently reviewing the history, physical signs, course, haematological and x-ray data; all dubious cases were discarded. The patients had the usual course of antibiotic treated pneumonia, except for one that proved to be staphylococcal in origin. Persistence of the illness, and the development of empyema after five days on ampicillin treatment were noted in this case.

\section{Discussion and Conclusion}

The results for blood levels attained correspond quite well with those reported in adults (Knudsen et al., 1961). A corollary of this is the absence of age as a determining factor in the group studied. The doubling of levels with doubling of dosage is similar to that reported by Rolinson and Stevens (1961).

In common with other penicillins, ampicillin does not appear to cross into the cerebrospinal fluid at all well, but may attain therapeutic levels when the meninges are inflamed. The levels attained in amniotic fluid were disappointingly low, with the dose and time interval used. Until further data are available on this aspect, the use of ampicillin as a prophylaxis in premature rupture of the membranes does not seem advisable.

In gastro-enteritis the drug may be of some value, although this conclusion could not be given with 
TABLE 8

GASTRO-ENTERITIS TRIAL: EFFECT OF AMPICILLIN ON SYMPTOMS OF PATIENTS WITH A STOOL PATHOGEN

\begin{tabular}{|c|c|c|c|c|c|c|c|c|}
\hline \multirow{3}{*}{ Day after Treatment } & \multicolumn{8}{|c|}{ Cumulative No. of Patients Cleared from Pathogen } \\
\hline & \multicolumn{2}{|c|}{ Mild Disease } & \multicolumn{2}{|c|}{ Moderate Disease } & \multicolumn{2}{|c|}{ Severe Disease } & \multicolumn{2}{|c|}{ All Grades of Severity } \\
\hline & Drug & Placebo & Drug & Placebo & Drug & Placebo & Drug & Placebo \\
\hline 4 & 3 & 3 & 0 & 1 & 1 & 0 & 4 & 4 \\
\hline 6 & 4 & 5 & 2 & 1 & 2 & $\mathbf{0}$ & 8 & 6 \\
\hline 8 & 4 & 6 & 3 & 1 & 3 & 2 & 10 & 9 \\
\hline Total treated & 5 & 7 & 8 & 3 & 3 & 5 & 12 & 15 \\
\hline
\end{tabular}

TABLE 9

GASTRO-ENTERITIS TRIAL: EFFECTS OF AMPICILLIN ON STOOL CULTURES OF PATIENTS WITH INTESTINAL PATHOGEN

\begin{tabular}{|c|c|c|c|c|c|c|c|c|}
\hline \multirow{3}{*}{ Day after Treatment } & \multicolumn{8}{|c|}{ Cumulative No. of Patients Cleared from Pathogen } \\
\hline & \multicolumn{2}{|c|}{ Mild Disease } & \multicolumn{2}{|c|}{ Moderate Disease } & \multicolumn{2}{|c|}{ Severe Disease } & \multicolumn{2}{|c|}{ All Grades } \\
\hline & Drug & Placebo & Drug & Placebo & Drug & Placebo & Drug & Placebo \\
\hline 4 & 2 & 1 & 3 & $\mathbf{0}$ & 2 & 1 & 7 & 2 \\
\hline 6 & 3 & 2 & 3 & $\mathbf{0}$ & 3 & 1 & 9 & 3 \\
\hline 8 & 3 & 4 & 3 & $\mathbf{0}$ & 3 & 2 & 9 & 6 \\
\hline Total treated & 7 & 7 & 4 & 4 & 3 & 5 & 14 & 16 \\
\hline
\end{tabular}

statistical backing. The small numbers in the trial tend to vitiate the results. However, a previous trial (Elliott, Maxwell and Robertson, 1961-62), comparing the activity of ampicillin and chloramphenicol in this disease, showed a slight trend in favour of ampicillin, particularly in salmonella infections. This is the group that fared better on ampicillin in the present trial.

It is unlikely that enteropathogenic Esch. coli infections were influenced by ampicillin since the inhibitory concentration in vitro required for these was high. Blood levels, however, are not a good guide to behaviour in vivo. Harrison and Stewart (1961) have postulated an enterohepatic recirculation of ampicillin resulting in low concentrations in the lower ileum and colon in animals. Certainly normal humans receiving ampicillin have negligible quantities in their faeces (Stewart, Coles, Nixon and Holt, 1961).

It is of interest that the mean blood levels of ampicillin attained in children with gastro-enteritis were lower than in children without this disease, possibly implying malabsorption. In turn this might be associated with higher colonic concen-

TABLE 10

GASTRO-ENTERITIS TRIAL: RESPONSE OF SYMPTOMS AND FAECAL CULTURES TO AMPICILLIN ACCORDING TO PATHOGEN TYPE

\begin{tabular}{|c|c|c|c|c|c|c|c|c|c|c|c|c|}
\hline \multirow{4}{*}{ Day after Admission } & \multicolumn{12}{|c|}{ Cumulative No. of Patients Cured } \\
\hline & \multicolumn{4}{|c|}{ Salmonella Group } & \multicolumn{4}{|c|}{ Shigella Group } & \multicolumn{4}{|c|}{ Pathogenic Esch. coli Group } \\
\hline & \multicolumn{2}{|c|}{ Symptoms } & \multicolumn{2}{|c|}{ Cultures } & \multicolumn{2}{|c|}{ Symptoms } & \multicolumn{2}{|c|}{ Cultures } & \multicolumn{2}{|c|}{ Symptoms } & \multicolumn{2}{|c|}{ Cultures } \\
\hline & Drug & Placebo & Drug & Placebo & Drug & Placebo & Drug & Placebo & Drug & Placebo & Drug & Placebo \\
\hline 4 & 1 & 0 & 3 & 0 & 1 & 1 & 3 & 2 & 2 & 4 & 1 & 0 \\
\hline 6 & 3 & 1 & 3 & $\mathbf{0}$ & 3 & 1 & 5 & 4 & 2 & 5 & 1 & $\mathbf{0}$ \\
\hline 8 & 6 & 2 & 3 & 1 & 4 & 3 & 5 & 4 & 2 & 5 & 1 & 1 \\
\hline Total treated .. & 6 & 6 & 6 & 6 & 4 & 4 & 6 & 4 & 2 & 7 & 2 & 7 \\
\hline
\end{tabular}


trations of the antibiotic. Larger doses may well enhance this desirable effect.

The notable efficacy of this antibiotic in renal tract infections (Brumfitt, Percival and Carter, 1962) is attributable both to its spectrum of activity and to its high renal excretion (Knudsen et al., 1961). Our results confirm its activity in the paediatric age-group.

Although ampicillin, being penicillinase sensitive, holds no advantage over penicillin G. in staphylococcal infections, its potential activity against $H$. influenzae (Rolinson and Stevens, 1961) is a distinct theoretical advantage.

Certainly all cases of pneumonia treated with ampicillin did well, apart from the one proven to be staphylococcal in origin. No cases of toxicity or sensitivity to ampicillin were noted in any of the children treated, with the exception of an urticarial reaction in a child with previous penicillin $V$. sensitivity.

\section{Summary}

Ampicillin is well absorbed in children, and appears to share the low toxicity of other penicillins. Its activity in gastro-enteritis of bacterial origin is promising and could probably be enhanced by larger doses. Its therapeutic efficiency in renal tract and pulmonary infections appears to be satisfactory.

This study was supported by a grant from the Adelaide Children's Hospital Research Fund.

\section{REFERENCES}

Brumfitt, W., Percival, A. and Carter, M. J. (1962). Treatment of urinary-tract infections with ampicillin; A clinical trial. Lancet, urinary 130 .

Elliott, R. B., Maxwell, G. M. and Kneebone, G. M. (1963). An appraisal of antibacterial therapy in childhood gastro-enteritis. Med. J. Aust., 2, 579.

, antibiotics in the treatment of childhood gastro-enteritis. Clin. rep. Adelaide Child. Hosp., 3, 323.

Harrison, P. M. and Stewart, G. T. (1961). Quoted by Knudsen, Rolinson and Stevens (1961).

Kneebone, G. M. and Maxwell, G. M. (1960). 6(Alpha-phenoxypropionamido) penicillanic acid potassium salt: Studies in the paediatric age group. Med. J. Aust., 2, 1002.

Knudsen, E. T., Rolinson, G. N. and Stevens, S. (1961). Absorption and excretion of 'penbritin'. Brit. med. J., 2, 198.

Rolinson, G. N. and Stevens, S. (1961). Microbiological studies on a new broad-spectrum penicillin, 'penbritin'. ibid., 2, 191.

Stewart, G. T., Coles, H. M. T., Nixon, H. H. and Holt, R. J. (1961) 'Penbritin': an oral penicillin with broad-spectrum activity. ibid., 2, 200. 